Research Article

\title{
Lack of detection of human papillomavirus DNA in prostate carcinomas in patients from northeastern Brazil
}

Ari P. Araujo-Neto ${ }^{1}$, Hygor Ferreira-Fernandes ${ }^{1}$, Carolina M.M. Amaral ${ }^{2}$, Lina G. Santos ${ }^{3}$, Antônio C. Freitas ${ }^{2}$, Jacinto C. Silva-Neto ${ }^{4}$, Juan A. Rey ${ }^{5}$, Rommel R. Burbano ${ }^{6}$, Benedito B. da Silva ${ }^{3}$, France K.N. Yoshioka ${ }^{1}$ and Giovanny R. Pinto ${ }^{1}$

${ }^{1}$ Laboratório de Genética e Biologia Molecular, Universidade Federal de Piauí, Parnaíba, PI, Brazil.

${ }^{2}$ Laboratório de Estudos Moleculares e Terapia Experimental, Departamento de Genética, Centro de Biociências, Universidade Federal de Pernambuco, Recife, PE, Brazil.

${ }^{3}$ Faculdade de Medicina, Universidade Federal do Piauí, Teresina, PI, Brazil.

${ }^{4}$ Laboratório de Pesquisas Citológica e Molecular, Departamento de Histologia e Embriologia, Centro de Biociências, Universidade Federal de Pernambuco, Recife, PE, Brazil.

${ }^{5}$ Molecular Oncogenetics Laboratory, Unidad de Investigación, Hospital Universitario La Paz, Paseo de la Castellana, Madrid, Spain.

${ }^{6}$ Laboratório de Citogenética Humana, Instituto de Ciências Biológicas, Universidade Federal de Pará, Belém, PA, Brazil.

\begin{abstract}
Prostate cancer is the second most common cancer among men in western populations, and despite its high mortality, its etiology remains unknown. Inflammatory processes are related to the etiology of various types of tumors, and prostate inflammation, in particular, has been associated with prostate cancer carcinogenesis and progression. Human papillomavirus (HPV) is associated with benign and malignant lesions in the anogenital tract of both females and males. The possible role of HPV in prostate carcinogenesis is a subject of great controversy. In this study, we aimed to examine the prevalence of HPV infections in prostate carcinomas of patients from northeastern Brazil. This study included 104 tissue samples from primary prostate carcinoma cases. HPV DNA was purified and then amplified using MY09/11 and GP5+/GP6+ degenerate primer sets that detect a wide range of HPV types, and with specific PCR primers sets for E6 and E7 HPV regions to detect HPV 16. None of the samples showed amplification products of HPV DNA for primer sets MY09/11 and GP5+/GP6+, or the specific primer set for the E6 and E7 HPV regions. HPV infection, thus, does not seem to be one of the causes of prostate cancer in the population studied.
\end{abstract}

Keywords: human papillomavirus, prostate cancer, prevalence, HPV PCR detection, molecular epidemiology.

Received: May 15, 2015; Accepted: October 1, 2015.

\section{Introduction}

Prostate cancer is the second most common cancer among men in western populations (Siegel et al., 2014). In Brazil, the National Cancer Institute estimated that approximately 69,000 new cases of this disease will be diagnosed in 2015, representing an increase of approximately 24\% compared to 2010 (Facina, 2014). Additionally, the mortality rate of prostate cancer has been showing a worrying rise in all regions of Brazil, especially in the Northeast, where the rate increased from 3.8 in 1980 to 14.3 deaths per 100,000 men in 2010 (Conceição et al., 2014). Since age is

Send correspondence to Giovanny Rebouças Pinto. Laboratório de Genética e Biologia Molecular, Universidade Federal do Piauí, Av. São Sebastião 2819, 64202-020 Parnaíba, PI, Brazil. E-mail: pintogr@ufpi.edu.br the main risk factor associated with prostate cancer, the increase in incidence and mortality of this malignancy can be attributed to increased life expectancy. In Brazil, the share of seniors is expected to increase from $6.9 \%$ in 2010 to $22.5 \%$ in 2050 (Pew Research Center, 2014). Thus, the development of strategies to control age-associated diseases, such as prostate cancer, is warranted. However, the limited knowledge regarding the etiology of prostate cancer is one of the main challenges associated with the development of preventive measures against this disease (Conceição et al., 2014).

Inflammatory processes are related to the etiology of various types of tumors, and prostate inflammation, in particular, has been associated with prostate cancer carcinogenesis and progression. Infections, especially sexually transmitted ones and those that reach the urogenital tract, are 
possible causes of intraprostatic inflammation. Infectious organisms are essential for the maintenance of local inflammatory processes, which can cause cellular changes responsible for genetic and epigenetic changes that lead to cell transformation (Sfanos et al., 2013). In this context, special emphasis is given to human papillomavirus (HPV). HPV is considered to be the most common cause of sexually transmitted infections, which are implicated in about $5 \%$ of all malignancies (Heidegger et al., 2015). The carcinogenesis of HPV depends on the integration of HPV DNA into the host genome and expression of the oncogenic viral proteins E6 and E7, which inhibit tumor suppressor proteins $\mathrm{p} 53$ and $\mathrm{pRb}$, leading to increasing genomic instability, accumulation of oncogene mutations, further loss of cell-growth control, and ultimately cancer (Heidegger et al., 2015).

Interest in the study of HPV has grown steadily since HPV DNA sequences were first detected in biopsies of anogenital cancer. Epidemiological evidence shows that men who develop anal cancer have a higher risk of developing prostate cancer (Rabkin et al., 1992). Previous and recent studies using serological and molecular technologies have suggested an association between infection with high-risk oncogenic HPV and prostate cancer (McNicol and Dodd, 1990; Anwar et al., 1992; Chen et al., 2011; Singh et al., 2015), but the results are still inconclusive, mainly because there is also evidence of the absence of this association (Effert et al., 1992; Bergh et al., 2007; Gazzaz and Mosli, 2009; Yow et al., 2014)

The prevalence of HPV DNA in tumor tissue of patients with prostate cancer has been poorly investigated in Brazil (Silvestre et al., 2009). Therefore, the present study examined for the first time the prevalence of HPV infections in prostate carcinomas of patients from northeastern Brazil.

\section{Subjects and Methods}

This single-center study included 104 patients admitted to the Hospital São Marcos in Teresina, State of Piauí, in the northeastern region of Brazil. The patients were con- secutively diagnosed with prostate cancer, with histopathological confirmation between August 2011 and July 2013. All patients enrolled in the study underwent radical prostatectomy as a first treatment option, and fresh frozen specimens of primary prostate tumors were provided by the Pathology Department of the Hospital which were preserved in RNAlater solution (Applied Biosystems, Inc. Foster City, CA) and stored at $-20^{\circ} \mathrm{C}$ until analysis date. The individuals signed informed consent forms, and the procedures were approved by the Universidade Federal do Piauí Ethics Committee in Research.

For DNA extraction, samples of tumor fragments (approximately $20 \mathrm{mg}$ ) were mechanically homogenized (handheld homogenizer, model D-130, Wiggenhause SDN BHD) in nuclear lysis solution (Wizard $\mathbb{R}$ Genomic Kit, Promega Inc., USA) and thereafter incubated with 20 $\mathrm{mg} / \mathrm{ml}$ proteinase $\mathrm{K}$ at $65^{\circ} \mathrm{C}$ for $12 \mathrm{~h}$ or until the fragment was completely digested. Subsequently, proteinase K was inactivated at $95^{\circ} \mathrm{C}$ for $15 \mathrm{~min}$ and the total product was used for DNA extraction in accordance with the recommendations of the kit manufacturer.

After isolation, the DNA concentration was determined using a Biospec-nano spectrophotometer (Shimadzu, Japan). The DNA obtained from the samples was submitted for amplification of the human MDM2 gene (Xiao et al., 2010) to verify integrity and quantity of DNA in the samples. Table 1 shows the primer sequences and protocols used to amplify HPV DNA sequences.

HPV DNA detection was performed by PCR amplification using the standard nested PCR approach with the MY09/11 primer set (outer primers) and the GP5+/6+ primer set (inner primers), which are degenerate primer sets that detect a wide range of HPV types (Aghakhani et al., 2011). Additionally, in an attempt to increase detection rate of HPV, a second inner primer set was used $(\operatorname{Pr} 1 / \operatorname{Pr} 2)$ for amplification of specific sequences of the E6 and E7 regions of HPV 16 (Karlsen et al., 1996). The cycling conditions were $94{ }^{\circ} \mathrm{C}$ for $3 \mathrm{~min}$ followed by 34 cycles of $94^{\circ} \mathrm{C}$ for $30 \mathrm{~s}, 55^{\circ} \mathrm{C}$ (for MY09/11), $45^{\circ} \mathrm{C}$ (for $\mathrm{GP} 5+/ 6+$ ) or 57 ${ }^{\circ} \mathrm{C}$ (for $\operatorname{Pr} 1 / \operatorname{Pr} 2$ ) for $1 \mathrm{~min}$ and $72{ }^{\circ} \mathrm{C}$ for $1 \mathrm{~min}$, with a final

Table 1 - Primers used for amplification of the region of interest, and size of the PCR product.

\begin{tabular}{|c|c|c|c|c|}
\hline Primers & Base sequence (5'-3') & $\mathrm{T}^{1}$ & Size & Product $(b p)^{2}$ \\
\hline MDM2 - F & GATTTCGGACGGCTCTCGCGG & $66,5^{\circ} \mathrm{C}$ & 21 & 121 \\
\hline MDM2 - R & CATCCGGACCTCCCGCGCTG & $66,5^{\circ} \mathrm{C}$ & 20 & \\
\hline MY09 & CGTCC(AC)A(AG)(AG)GGA(T)ACTGATC & $55^{\circ} \mathrm{C}$ & 23 & 450 \\
\hline MY11 & GC(AC)CAGGG(AT)CATAA(CT)AATGG & $55^{\circ} \mathrm{C}$ & 23 & \\
\hline GP5+ & TTTGTTACTGTGGTAGATACTAC & $45^{\circ} \mathrm{C}$ & 23 & 150 \\
\hline GP6+ & GAAAAATAAACTGTAAATCATATTC & $45^{\circ} \mathrm{C}$ & 25 & \\
\hline Pr1 (HPV-16) & TCAAAAGCCACTGTGTCCTGA & $57^{\circ} \mathrm{C}$ & 21 & 119 \\
\hline Pr2 (HPV-16) & CGTGTTCTTGATGATCTGCAA & $57^{\circ} \mathrm{C}$ & 21 & \\
\hline
\end{tabular}

${ }^{1} \mathrm{~T}$ : annealing temperature; ${ }^{2} \mathrm{bp}$ : base pairs 
extension step at $72{ }^{\circ} \mathrm{C}$ for $10 \mathrm{~min}$. The reaction mix was prepared with $4 \mu \mathrm{L}$ DNA (200 ng), $1.6 \mu \mathrm{M}$ of each primer and $12.5 \mu \mathrm{L}$ MasterMix, in a total volume of $25 \mu \mathrm{L}$. The PCR products were visualized on a $2 \%$ agarose gel with ethidium bromide under UV light. Each positive sample was then bidirectionally sequenced using the BigDye ${ }^{\circledR}$ Terminator v.3.1 Cycle Sequencing Kit.

Each batch of samples included negative controls without a DNA template, and a positive control, which consisted of a sample of DNA from uterine cervix cells (200 ng) known to be infected with HPV.

\section{Results}

One hundred and four prostate carcinoma samples were analyzed from patients aged between 45 and 90 years (mean $=68 \pm 8.5$ years). Tumors were staged using standard criteria by the Gleason score and TNM staging system, according to the 7th revision of the TNM classification, 2010. No sample had a Gleason score lower than 6. Table 2 shows the cases along with their clinico-pathological characteristics. Because this study had a retrospective design, complete information was lacking for some patients due to a lack of information about the registration of clinical pathologists.

The success rate for amplification using $M D M 2$ gene primers was $100 \%$, indicating that a large quantity of DNA was extracted from the tumors (ranging from 410 to 1880 $\mathrm{ng} / \mu \mathrm{L}$, Figures S1 and S2). However, none of the samples

Table 2 - Clinico-pathological characteristics of the samples

\begin{tabular}{lc}
\hline Variable & Prostatic tumors $(\mathrm{n}=104)$ \\
\hline Mean age (SD) & $68 \pm 8.5$ \\
Gleason Grade $(\mathrm{n}=97)$ & $6.2 \%$ \\
Low (Gleason 2-6) & $60.8 \%$ \\
Moderate (Gleason 7) & $33.0 \%$ \\
High (Gleason 8-10) & \\
Tumor extension $(\mathrm{n}=96)$ & $5.2 \%$ \\
T1 & $21.9 \%$ \\
T2 & $64.6 \%$ \\
T3 & $8.3 \%$ \\
T4 & \\
Regional lymph nodes $(\mathrm{n}=74)$ & $85.1 \%$ \\
Absent & $14.9 \%$ \\
Present & \\
Distant metastasis $(\mathrm{n}=59)$ & $86.4 \%$ \\
Absent & $13.6 \%$ \\
Present & \\
HPV DNA (n=104) & $100 \%$ \\
Absent & $0 \%$ \\
Present &
\end{tabular}

showed amplification products of HPV DNA for primer sets MY09/MY11 and GP5/GP6, or the specific primer set for the E6 and E7 HPV regions. In an attempt to reach a higher assay sensibility, the analyses were repeated using a GP5/GP6 auto-nested PCR approach, as described by Remmerbach et al. (2004). However again, all samples tested negative for HPV DNA.

\section{Discussion}

Since 1990, studies in several countries have attempted to detect HPV DNA in prostate carcinomas using different detection methods. Some studies suggested that prostate carcinomas are related to HPV infection and have shown the presence of HPV DNA to varying degrees (from 2 to $100 \%$ ), but even after several years of HPV DNA analysis in benign and malignant prostate samples, it is still unclear if HPV causes prostate carcinogenesis (Heidegger $e t$ al., 2015).

McNicol and Dodd (1990) were the first to demonstrate HPV genomic sequences in prostate tissues. They found that 14 of $15(93.3 \%)$ benign prostatic hyperplasia (BPH) samples from Canadian patients, and all four carcinomas (100\%), tested positive for HPV 16. Subsequent studies, such as the one by Anwar et al. (1992), provided further evidence to support a relationship between HPV and prostate cancer. According to their results, HPV DNA was present in $28(41 \%)$ out of 68 prostate carcinomas cases from Japanese patients and was not detected in any of the normal or hyperplastic prostatic tissues (10 each), which is consistent with recent findings in other populations, such as the ones from Greece and India (Michopoulou et al., 2014; Singh et al., 2015).

In contrast, several studies have found that HPV DNA is not preferentially associated with either BPH or prostate cancer. Tachezy et al. (2012) found no association between the persistence of HPV infection and the risk of developing prostate cancer, reporting the same prevalence of HPV DNA (2\%) in 210 samples of tissues from 95 patients with BPH and in 90 samples of 51 patients with prostatic cancer. Other studies have detected HPV DNA sequences in approximately $12-65 \%$ of malignant and in $5-48 \%$ of benign prostatic samples, and no statistically significant difference was shown (Carozzi et al., 2004; Aghakhani et al., 2011; Chen et al., 2011; Ghasemian et al., 2013). Based on these findings, it can be concluded that the prostate gland is a potential reservoir for transmission of HPV types with oncogenic potential. However, the HPV DNA findings in prostate tissue do not necessarily reflect active infection, or that the prostatic disease was caused by HPV; they could very well represent transient infections. Thus, while the prostate may act as a site for HPV replication, it is unlikely that HPV is directly involved in the transformation of prostatic cells (Dodd et al., 1993; Aghakhani et al., 2011). On the other hand, the presence of high-risk HPV DNA in subsets of prostate cancers shows that at least 
a proportion of prostate cancers may be related to HPV infection.

In this study we were unable to identify the presence of HPV DNA in any of the 104 samples of prostate carcinoma in patients from northeastern Brazil. Our results are consistent with other previously and recently published reports. Effert et al. (1992) analyzed 30 paraffin-embedded prostate adenocarcinomas for the presence of HPV 16- or HPV 18-specific sequences by differential PCR (D-PCR) and Southern blot analysis. Despite the high sensitivity of their analytical technique, they found no evidence of HPV DNA of either type in any of the 30 primary prostate cancers. Furthermore, Bergh et al. (2007), in an investigation of 201 prostate tissue samples of patients with BPH that later progressed to prostate cancer and of 201 matched controls, found that all samples tested were negative for HPV, thus making it an unlikely contributing factor for subsequent cancer development. Gazzaz and Mosli (2009) did not detect HPV DNA by hybrid capture 2 technology among 56 tested biopsies categorized into a benign lesion pattern of prostatic hyperplasia, malignant, and inflammatory disorders. Yow et al. (2014) achieved the same result after analyzing 195 archival paraffin-embedded tissue blocks by PCR.

Inconsistent results may be due to technical difficulties in HPV DNA detection. There are several possible reasons for false-positive or false-negative results, most notably PCR contamination, degradation, or cross-contamination of DNA, and tumor samples that are not representative (Terris and Peehl, 1997; Adami et al., 2003; Gazzaz and Mosli, 2009). Moreover, considering that HPV presence is strongly associated with high-risk sexual behavior, including a history of sexually transmitted diseases (STDs), the number of sexual partners, and age of first sexual activities, a comparison of cancers from patients with such sexual activity vs. those who did not engage in high-risk behavior may have shown different results.

The distribution of HPV varies among different populations, and infection rates are influenced by geography, age, sexual history, coinfections, immune status, and genetic factors (Vesco et al., 2011). In Brazil, the overall prevalence of HPV infection among women, not stratified by cervical cytology results, ranged from $16.8 \%$ to $28.6 \%$ (Ayres and Silva, 2010). In men, HPV can be present in up to $72 \%$ of the samples of the male genital region, as was reported in a study on a population of southeastern Brazil (Freire et al., 2011). To our knowledge, the only study of the potential association between HPV and prostate cancer in Brazil was performed by Silvestre et al. (2009), in which the authors reported a 3\% prevalence of HPV DNA in samples of prostatic carcinoma in a northern Brazilian population. In the northeastern region of Brazil, data on HPV prevalence are scarce, both in females and in males. On the other hand, in a study in this population, Silva Jr and da Silva (2011) investigated the prevalence of HPV DNA in
79 samples of breast ductal carcinoma and reported the absence of HPV types $6,11,16$, and 18 . Therefore, the results presented here, as well as those of Silva Jr and da Silva (2011) are important reports on the prevalence of HPV in neoplastic tissues in the northeastern population of Brazil.

Some limitations of this study should be taken into consideration. Although we used a relatively large sample size $(\mathrm{n}=104)$ compared to other studies (McNicol and Dodd, 1990; Anwar et al., 1992; Effert et al., 1992; Carozzi et al., 2004; Gazzaz and Mosli, 2009; Chen et al., 2011; Michopoulou et al., 2014; Singh et al., 2015), the lack of association observed in this study may have been a result of the limited number of samples analyzed. Moreover, it would be useful to use complementary approaches for the direct and indirect detection of HPV to confirm our negative results. However, although serologic analysis is often used in combination with molecular analysis (Chen et al., 2011, Tachezy et al., 2012), this method is limited in that it reflects overall exposure to HPV and does not distinguish HPV infections within specific anatomical sites (Chen et al., 2011). The molecular technique used in this study (nested PCR) is one of the most sensitive for the detection of HPV DNA in clinical specimens when combined with the sequencing of positive samples, as previously included in the study design (Chaiwongkot et al., 2007). The set of primers used and the quality of DNA analyzed are the main variables that may cause errors when attempting to detect HPV DNA by PCR (Terris et al., 1997). However, the set of primers used in this study is well established in the literature, and amplification of the MDM2 gene revealed that $100 \%$ of the samples had sufficient high quality DNA for subsequent reactions.

In conclusion, our study showed no evidence to support the hypothesis that HPV infection is related to the development of prostate cancer in patients from northeastern Brazil, given that the prevalence of these pathogens in the population studied was null. Additional studies involving larger sample size and that take into account other confounding variables such as sexual behavior should be carried out to elucidate the role of HPV in prostatic carcinogenesis.

\section{Acknowledgments}

This study was supported by the National Counsel of Technological and Scientific Development (Conselho Nacional de Desenvolvimento Científico e Tecnológico, CNPq; grant number 502193/2009-3) and by the Coordination of Improvement of Higher Education (Coordenação de Aperfeiçoamento de Pessoal de Nível Superior; CAPES).

\section{References}

Adami HO, Kuper H, Andersson SO, Bergström R and Dillner J (2003) Prostate cancer risk and serologic evidence of human papilloma virus infection: a population-based case-control study. Cancer Epidemiol Biomarkers Prev 12:872-875. 
Aghakhani A, Hamkar R, Parvin M, Ghavami N, Nadri M, Pakfetrat A, Banifazl M, Eslamifar A, Izadi N, Jam S et al. (2011) The role humam papillomavirus infection in prostate carcinoma. Scand J Infect Dis 43:64-69.

Anwar K, Nakakuki K, Shiraishi T, Naiki H, Yatani R and Inuzuka M (1992) Presence of ras oncogene mutations and human papillomavirus DNA in human prostate carcinomas. Cancer Res 52:5991-5996.

Ayres AR and Silva GA (2010) Cervical HPV infection in Brazil: systematic review. Rev Saude Publica 44:963-974.

Bergh J, Marklund I, Gustavsson C, Wiklund F, Grönberg H, Allard A, Alexeyev O and Elgh F (2007) No link between viral findings in the prostate and subsequent cancer development. Br J Cancer 96:137-139.

Carozzi F, Lombardi FC, Zendron P, Confortini M, Sani C, Bisanzi S, Pontenani G and Ciatto S (2004) Association of human papillomavirus with prostate cancer: analysis of a consecutive series of prostate biopsies. Int J Biol Markers 19:257-261.

Chaiwongkot A, Pientong C, Ekalaksananan T, Kongyingyoes B, Thinkhamrop J, Yuenyao P and Sriamporn S (2007) Evaluation of primers and PCR performance on HPV DNA screening in normal and low grade abnormal cervical cells. Asian Pac J Cancer Prev 8:279-282.

Chen $\mathrm{ACH}$, Waterboer T, Keleher A, Morrison B, Jindal S, McMillan D, Nicol D, Gardiner RA, McMillan NA and Antonsson A (2011) Human papillomavirus in benign prostatic hyperplasia and prostatic adenocarcinoma patients. Pathol Oncol Res 17:613-617.

Conceição MB, Boing AF and Peres KG (2014) Time trends in prostate cancer mortality according to major geographic regions of Brazil: an analysis of three decades. Cad Saude Publica 30:559-566.

Dodd JG, Paraskevas M and McNicol PJ (1993) Detection of human papillomavirus 16 transcription in human prostate tissue. J Urol 149:400-402.

Effert PJ, Frye RA, Neubauer A, Liu ET and Walther PJ (1992) Human papillomavirus types 16 and 18 are not involved in human prostate carcinogenesis: analysis of archival human prostate cancer specimens by differential polymerase chain reaction. J Urol 147:192-196.

Facina T (2014) Estimativa 2014 - Incidência de Câncer no Brasil. Rev Bras Cancerol 60:63.

Freire MP, Pires D, Forjaz R, Sato S, Cotrim I, Stiepcich M, Scarpellini B and Truzzi JC (2011) Genital prevalence of HPV types and co-infection in men. Int Braz J Urol 40:67-71.

Gazzaz FS and Mosli HA (2009) Lack of detection of human papillomavirus infection by hybridization test in prostatic biopsies. Saudi Med J 30:633-637.

Ghasemian E, Monavari SH, Irajian GR, Jalali Nodoshan MR, Roudsari RV and Yahyapour Y (2013) Evaluation of human papillomavirus infections in prostatic disease: a crosssectional study in Iran. Asian Pac J Cancer Prev 14:3305-8.

Heidegger I, Borena W and Pichler R (2015) The role of human papilloma virus in urological malignancies. Anticancer Res 35:2513-2519.

Karlsen F, Kalantari M, Jenkins A, Pettersen E, Kristensen G, Holm R, Johansson B and Hagmar B (1996) Use of multiple PCR primer sets for optimal detection of human papillomavirus. J Clin Microbiol 34:2095-2100.
McNicol PJ and Dodd JG (1990) Detection of human papillomavirus DNA in prostate gland tissue by using the polymerase chain reaction amplification assay. J Clin Microbiol 28:409-412.

Michopoulou V, Derdas SP, Symvoulakis E, Mourmouras N, Nomikos A, Delakas D, Sourvinos G and Spandidos DA (2014) Detection of human papillomavirus (HPV) DNA prevalence and p53 codon 72 (Arg72Pro) polymorphism in prostate cancer in a Greek group of patients. Tumor Biol 35:12765-73.

Nakai Y and Nonomura N (2013) Inflammation and prostate carcinogenesis. Int J Urol 20:150-60.

Rabkin CS, Biggar RJ, Melbye M and Curtis RE (1992) Second primary cancers following anal and cervical carcinoma: evidence of shared etiologic factors. Am J Epidemiol 136:5458 .

Remmerbach TW, Brinckmann UG, Hemprich A, Chekol M, Kühndel K and Liebert UG (2004) PCR detection of human papillomavirus of the mucosa: comparison between MY09/11 and GP5+/6+ primer sets. J Clin Virol 30:302-8.

Sarkar FH, Sakr WA, Li YW, Sreepathi P and Crissman JD (1993) Detection of human papillomavirus (HPV) DNA in human prostatic tissues by polymerase chain reaction (PCR). Prostate 22:171-180.

Sfanos KS, Isaacs WB and De Marzo AM (2013) Infections and inflammation in prostate cancer. Am J Clin Exp Urol 1:3-11.

Siegel R, Ma J, Zou Z and Jemal A (2014) Cancer statistics, 2014. CA Cancer J Clin 64: 9-29.

Silva Jr RG and da Silva BB (2011) No evidence for an association of human papillomavirus and breast carcinoma. Breast Cancer Res Treat 125:261-264.

Silvestre RVD, Leal MF, Demachki S, Nahum MC, Bernardes JG, Rabenhorst SH, Smith Mde A, Mello WA, Guimarães AC and Burbano RR (2009) Low frequency of human papillomavirus detection in prostate tissue from individuals from Northern Brazil. Mem Inst Oswaldo Cruz 104:665667.

Singh N, Hussain S, Kakkar N, Singh SK, Sobti RC and Bharadwaj $M$ (2015) Implication of high risk human papillomavirus HR-HPV infection in prostate cancer in Indian population - a pioneering case-control analysis. Sci Rep 5:e7822.

Tachezy R, Jan Hrbacek J, Heracek J, Salakova M, Smahelova J, Ludvikova V, Svec A, Urban M and Hamsikova E (2012) HPV persistence and its oncogenic role in prostate tumors. J Med Virol 84:1636-1645.

Terris MK and Peehl DM (1997) Human papillomavirus detection by polymerase chain reaction in benign and malignant prostate tissue is dependent on the primer set utilized. Urology $50: 150-156$

Vesco KK, Whitlock EP, Eder M, Burda BU, Senger CA and Lutz K (2011) Risk factors and other epidemiologic considerations for cervical cancer screening: a narrative review for the U.S. Preventive Services Task Force. Ann Intern Med 155:698-705.

Xiao M, Zhang L, Zhu X, Huang J, Jiang H, Hu S and Liu Y (2010) Genetic polymorphisms of MDM2 and TP53 genes are associated with risk of nasopharyngeal carcinoma in a Chinese population. BMC Cancer 10:e147.

Yow MA, Tabrizi SN, Severi G, Bolton DM, Pedersen J, Longano A, Garland SM, Southey MC and Giles GG (2014). Detec- 
tion of infectious organisms in archival prostate cancer tissues. BMC Cancer 14:e579.

\section{Internet Resources}

Pew Research Center (2014) Attitudes about aging: a global perspective. [Data file and code book]. Washington DC, http:www.pewresearch.org (accessed Feb 12, 2015).

\section{Supplementary Material} ticle:
The following online material is available for this ar-
Figure S1 - Agarose gel electrophoresis of total DNA extracted from prostate tissue.

Figure S2 - Amplification of the DNA extracted from prostate tissue.

This material is available as part of the online article from http://www.scielo.br/gmb

Associate Editor: Carlos F. M. Menck

License information: This is an open-access article distributed under the terms of the Creative Commons Attribution License (type CC-BY), which permits unrestricted use, distribution and reproduction in any medium, provided the original article is properly cited. 